\title{
PENERAPAN ALGORITMA NAÏVE BAYES DENGAN BACKWARD ELIMINATION UNTUK PREDIKSI WAKTU TUNGGU ALUMNI MENDAPATKAN PEKERJAAN
}

\author{
Abimanyu Widhiantoyo ${ }^{1}$, Betha N Sari², Dadang Yusup ${ }^{3}$ \\ 1,2,3Program Studi Teknik Informatika, Fakultas Ilmu Komputer, Universitas Singaperbangsa Karawang \\ Email: ${ }^{1}$ abimanyu.widhiantoyo17032@student.unsika.ac.id, ${ }^{2}$ betha.nurina@ staff.unsika.ac.id, \\ ${ }^{3}$ dadang.dyf@staff.unsika.ac.id
}

(Naskah masuk: 1 Juli 2021, diterima untuk diterbitkan: 13 Agustus 2021)

\begin{abstract}
Abstrak
Perguruan tinggi memiliki peranan yang signifikan dalam pengembangan kualitas pendidikan manusia. Merancang kurikulum dan strategi pendidikan yang tepat dapat menghasilkan lulusan yang berkualitas. Tracer Study menjadi salah satu metode untuk melacak status pekerjaan alumni setelah lulus dari pendidikannya. Fasilkom Unsika adalah salah satu fakultas yang ada di Universitas Singaperbangsa Karawang. Dari banyaknya jumlah lulusan yang dihasilkan, sejauh ini di Fasilkom Unsika belum pernah dilakukan pelacakan terhadap status pekerjaan alumni. Oleh karena itu pelacakan perlu dilakukan untuk nantinya dilakukan proses Data Mining. Dari proses Data Mining kemudian dihasilkan suatu pengetahuan. Penelitian ini bertujuan untuk memprediksi waktu tunggu alumni mendapatkan pekerjaan dengan menggunakan algoritma Nä̈ve Bayes dan dibandingkan dengan algoritma Nä̈ve Bayes dengan fitur seleksi Backward Elimination. Metodologi Data Mining yang digunakan yaitu Cross-Industry Standard Process for Data Mining (CRISP-DM). Penelitian menggunakan kelas label CEPAT dan LAMBAT dengan menerapkan sembilan skenario K-Folds Cross Validation. Hasilnya menunjukkan bahwa algoritma Nä̈ve Bayes dengan fitur seleksi Backward Elimination meraih performa terbaik dengan nilai Accuracy 68,52\% dan Kappa 0,370. Kesimpulan dari penelitian ini yaitu algoritma Nä̈ve Bayes dengan fitur seleksi Backward Elimination terbutki dapat meningkatkan hasil evaluasi pada prediksi waktu tunggu alumni mendapatkan pekerjaan.
\end{abstract}

Kata kunci: Nä̈ve Bayes, Backward Elimination, CRISP-DM, Waktu Tunggu Kerja Alumni

\section{IMPLEMENTATION OF NAÏVE BAYES WITH BACKWARD ELIMINATION FOR PREDICTING THE WAITING TIME FOR ALUMNI EMPLOYMENT}

\begin{abstract}
Universities have a significant role in developing the quality of human education. Designing the right curriculum and educational strategy can produce quality graduates. Tracer Study is one of the method to track alumni employment status after graduating from education. Fasilkom Unsika is one of the faculties at Singaperbangsa Karawang University. From the large number of graduates produced, so far at Fasilkom Unsika, no tracking has been carried out on the employment status of alumni. Therefore, tracking needs to be done to later carry out the Data Mining process. From the Data Mining process, knowledge is then generated. This study aims to predict the waiting time for alumni employment using the Nä̈ve Bayes algorithm and compared againts the Naive Bayes algorithm with the Backward Elimination selection feature. The Data Mining methodology used is Cross-Industry Standard Process for Data Mining (CRISP-DM). The study used the FAST and SLOW label classes by applying nine scenarios of K-Folds Cross Validation. The results show that the Nä̈ve Bayes algorithm with the Backward Elimination selection feature achieves the best performance with an Accuracy value of $68.52 \%$ and Kappa 0.370 . The conclusion of this study is that the Nä̈ve Bayes algorithm with the Backward Elimination selection feature is proven to be able to improve the evaluation results in predicting the waiting time for alumni to get a job.
\end{abstract}

Keywords: Nä̈ve Bayes, Backward Elimination CRISP-DM, Alumni Employment Waiting Time

\section{PENDAHULUAN}

Perguruan tinggi memiliki peranan yang signifikan dalam pengembangan kualitas pendidikan manusia. Merancang kurikulum dan strategi pendidikan yang tepat dapat menghasilkan lulusan yang berkualitas. Secara khusus, perguruan tinggi perlu mengidentifikasi potensi karir bagi mahasiswa. Kemampuan untuk memprediksi waktu tunggu 
alumni dalam memperoleh pekerjaan dapat menjadi pengetahuan bagi perguruan tinggi. Pengetahuan tersebut dapat digunakan pihak perguruan tinggi untuk mengevaluasi kinerja dari kurikulum dan strategi pendidikan yang dijalankan selama ini [1].

Setiap perguruan tinggi memiliki strategi dan caranya tersendiri untuk dapat membentuk lulusan yang siap bersaing di dunia kerja. Tracer Study menjadi salah satu metode dan hal penting bagi perguruan tinggi untuk melacak jejak alumni setelah lulus dari pendidikannya sampai ke dunia kerja. Badan Akreditasi Nasional Perguruan Tinggi (BANPT) menjadikan Tracer Study sebagai salah satu penilaian dan juga dijadikan sebagai salah satu syarat kelengkapan akreditasi [2].

Fakultas Ilmu Komputer (Fasilkom) adalah salah satu fakultas yang ada di Universitas Singaperbangsa Karawang (Unsika). Terhitung dari tahun 2012-2020, Fasilkom Unsika telah menghasilkan 1335 lulusan. Dari banyaknya jumlah lulusan tersebut, sejauh ini di Fasilkom Unsika belum pernah dilakukan pelacakan terhadap status pekerjaan alumni saat ini. Oleh karena itu pelacakan perlu dilakukan untuk mengetahui bagaimana status pekerjaan alumni saat ini. Dari pelacakan tersebut nantinya dilakukan proses Data Mining untuk kemudian dihasilkan suatu pengetahuan.

Penelitian sebelumnya dengan algoritma Naive Bayes telah dilakukan oleh Asroni dkk untuk perkiraan masa tunggu alumni mendapatkan pekerjaan. [3] Penelitian tersebut menggunakan metode Data Mining dan algoritma Nä̈ve Bayes untuk melakukan klasifikasi. Didapat kesimpulan bahwa algoritma Nä̈ve Bayes dapat digunakan untuk memprediksi masa tenggang alumni mendapat pekerjaan dengan tingkat Accuracy dan Performance Vector yaitu $71 \%$.

Penelitian selanjutnya oleh Maricar dkk tentang perbandingan akurasi Naive Bayes dan KNN untuk meramalkan status pekerjaan alumni ITB STIKOM Bali. [4] Dihasilkan kesimpulan bahwa metode Nä̈ve Bayes maupun KNN mampu menjadi solusi untuk klasifikasi atau prediksi terhadap data alumni.

Penelitian lainnya oleh Adyana tentang implementasi algoritma Nä̈ve Bayes untuk memprediksi waktu tunggu alumni dalam memperoleh pekerjaan. [5] Penelitian tersebut menggunakan metode Nä̈ve Bayes dengan proses data selection dan preprocessing pada dataset. Evaluasi dihasilkan nilai akurasi sebesar 48,629\% dengan parameter pengujian 10-Folds Cross Validation.

Penelitian ini menerapkan fitur seleksi Backward Elimination pada algoritma Nä̈ve Bayes. Backward Elimination merupakan salah satu metode seleksi fitur yang dapat mengoptimalkan akurasi model. Metode ini bekerja dengan cara pemilihan mundur, kemudian melakukan pengujian terhadap seluruh atribut-atribut yang dianggap tidak sesuai dan tidak terlalu berpengaruh terhadap pemodelan [6].
Tujuan dari penelitian ini untuk memperoleh tingkat akurasi terbaik antara pemodelan algoritma Nä̈ve Bayes dengan algoritma Nä̈ve Bayes + Backward Elimination. Selain itu juga dilakukan analisis terkait atribut paling berpengaruh terhadap proses pemodelan.

\section{METODE PENELITIAN}

Penelitian dilakukan dengan menggunakan data status pekerjaan alumni Fasilkom Unsika yang diperoleh melalui proses pelacakan dengan formulir daring yang disebar kepada 1335 alumni dimulai tanggal 22 April 2021 sampai dengan 20 Mei 2021.

Metodologi penelitian yang digunakan sesuai dengan tahapan proses Cross-Industry Standard Process for Data Mining (CRISP-DM) sebagai berikut [7]:

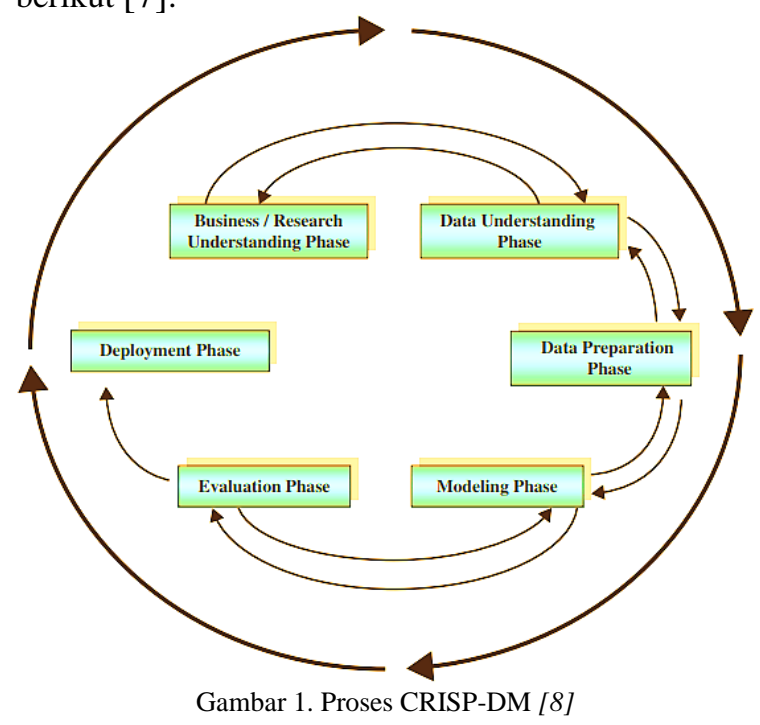

\subsection{Business Understanding (Pemahaman Bisnis)}

Terhitung sejak tahun 2012-2020 Fasilkom Unsika telah menghasilkan ribuan lulusan, dari banyaknya jumlah lulusan tersebut, sejauh ini di Fasilkom Unsika belum pernah dilakukan pelacakan terhadap status pekerjaan alumni saat ini. Penelitian ini bertujuan untuk memprediksi waktu tunggu alumni Fasilkom Unsika mendapatkan pekerjaan. Atribut yang menjadi label yaitu atribut "Lama Waktu Mendapatkan Pekerjaan" yang terbagi ke dalam dua kelas yaitu kelas "CEPAT" dan kelas "LAMBAT".

\subsection{Data Understanding (Pemahaman Data)}

Data diperoleh melalui pelacakan dengan menggunakan formulir daring yang disebar keseluruh alumni. Data terkumpul sebanyak $34,53 \%$ dari keseluruhan alumni yang terdiri dari 461 record data dengan 19 atribut di dalamnya. 


\subsection{Data Preparation (Persiapan Data)}

Pada tahap ini dilakukan proses seleksi data, pembersihan data, transformasi data, dan format data. Berikut ini tabel seleksi data:

\begin{tabular}{clc}
\multicolumn{2}{c}{ Tabel 1. Seleksi Data } \\
\hline No & \multicolumn{1}{c}{ Atribut } & Keterangan \\
\hline 1 & Nama & $\times$ \\
2 & NPM & $\times$ \\
3 & Tempat Lahir & $\times$ \\
4 & Tanggal Lahir & $\checkmark$ \\
5 & Jenis Kelamin & $\checkmark$ \\
6 & Angkatan & $\checkmark$ \\
7 & Tahun Lulus & $\checkmark$ \\
8 & IPK & $\checkmark$ \\
9 & Lama Studi & $\checkmark$ \\
10 & Riwayat Organisasi/Kepanitiaan & $\checkmark$ \\
11 & Pengalaman Magang/Kerja & $\checkmark$ \\
12 & Memiliki Sertifikasi Keahlian & $\times$ \\
13 & Status Pekerjaan & $\checkmark$ \\
14 & Lama Waktu Mendapatkan Pekerjaan & $\checkmark$ \\
15 & Bidang Pekerjaan & $\checkmark$ \\
16 & Jenis Perusahaan & $\times$ \\
17 & Posisi Pekerjaan & $\checkmark$ \\
18 & Kota Tempat Bekerja & $\checkmark$ \\
19 & Kesesuaian Bidang Pekerjaan dengan & \\
& TI & \\
\hline
\end{tabular}

Keterangan:

$\checkmark=$ Atribut terpilih

$x=$ Atribut tidak terpilih

Terdapat dua atau lebih data yang menjadi representasi rangkap dari entitas yang sama disebut duplikasi data. oleh karena itu perlu dilakukan perbandingan terhadap duplikasi data kemudian menghapus salah satunya [9]. Data yang hilang adalah keadaan dimana ada variabel pada atribut yang tidak memiliki nilai untuk dianalisis dan menjadi bias sehingga memungkinkan hasil dari analisis menjadi tidak valid. Salah satu cara untuk mengatasi data yang hilang adalah dengan menghapusnya [10]. Penyimpangan pada data yang bisa terlalu tinggi atau terlalu rendah dibanding dengan data lainnya disebut data outlier [11].

Saat dianalisis, pada dataset terdapat 4 duplikasi data dan 1 data outlier. Selain itu juga terdapat missing value pada 7 atribut dengan missing value terbesar yaitu 172 missing value pada atribut Jenis Perusahaan, Kota Tempat Bekerja, dan Kesesuaian Bidang Pekerjaan dengan TI. Setelah melalui tahap pembersihan data, data dikurangi dari 461 record menjadi 270 record. Proses dilakukan dengan menghapus duplikasi data, data yang hilang, dan data outlier.

Transformasi data dilakukan karena adanya salah penulisan dan juga data imbalanced. Klasifikasi yang hanya berjalan pada kelas mayoritas dapat menyebabkan penurunan tingkat akurasi yang disebut juga data dengan kelas yang tidak seimbang (data imbalanced) [12]. Hasil yang keliru seringkali ditemui pada banyak penelitian dengan analisis data imbalanced. Untuk melanjutkan proses analisis data, penanganan khusus perlu dilakukan [13].
Transformasi dilakukan pada atribut Kota Tempat Bekerja, Lama Studi, dan Lama Waktu Mendapatkan Pekerjaan.

Format data akhir yang telah siap digunakan untuk proses pemodelan yaitu sebanyak 270 record data dengan 12 atribut utama dan 1 atribut label.

\subsection{Modeling (Pemodelan)}

Penerapan algoritma Nä̈ve Bayes dilakukan pada tahap pemodelan terhadap dataset yang telah diolah sebelumnya pada fase data preparation Nä̈ve Bayes dapat beroperasi lebih baik dalam kasus dunia nyata yang kompleks dan tidak harus memiliki data latih yang banyak dalam proses klasifikasi untuk menentukan parameter ataupun pola. Berikut ini persamaan dari teorema bayes [14]:

$$
P(H / X)=\frac{P(X / H) \cdot P(H)}{P(X)}
$$

Tahapan proses Nä̈ve Bayes yaitu pada Gambar 2 berikut [15]:

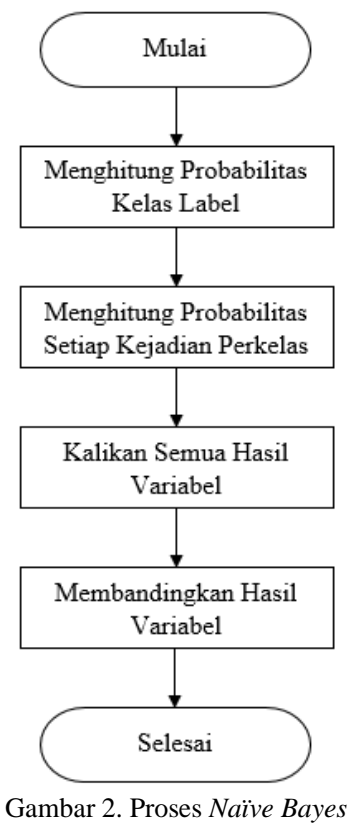

\subsection{Evaluation (Evaluasi)}

Model terbaik nantinya akan dipilih berdasarkan hasil evaluasi yang diperoleh. K-Fold Cross Validation dapat digunakan untuk memperoleh perkiraan yang tidak bias dari kinerja model pada jumlah data yang terbatas [16]. Pada proses klasifikasinya, masing-masing bagian akan membagi data secara acak ke dalam k bagian dengan ukuran yang sama. Penggunaan nilai $\mathrm{k}=10$ atau 10 -Folds Cross Validation secara umum sangat dianjurkan karena merupakan jumlah fold terbaik untuk uji validitas [17]. Confusion Matrix digunakan sebagai alat ukur untuk mengetahui kinerja dari algoritma. Pengujian menggunakan 9 skenario uji yaitu 2-folds, 
3-folds, ..., 10-folds. Dari 9 skenario nantinya dipilih skenario yang memiliki hasil kinerja terbaik [18].

\subsection{Deployment (Penyebaran)}

Disajikan hasil pemodelan algoritma Nä̈ve Bayes yang dibandingkan dengan pemodelan algoritma Nä̈ve Bayes + Backward Elimination. Analisis juga dilakukan terhadap atribut yang berpengaruh terhadap pemodelan

\section{HASIL DAN PEMBAHASAN}

Pemodelan terhadap dataset dilakukan menggunakan algoritma Naive Bayes dengan bantuan tools RapidMiner Studio. RapidMiner Studio dapat membantu aktivitas analisis prediktif dengan proses kerja dan penggunaan yang mudah. Begitu juga dengan proses data mining seperti data cleansing, filtering, clustering, dll yang mudah digunakan [19]. Tahapan proses Naive Bayes sebagai berikut:

\subsection{Hasil}

1. Menghitung Probabilitas Kelas Label Setelah melalui beberapa proses pengolahan data, data yang digunakan yaitu sebesar 270 record data yang terdiri dari total 12 atribut dan 1 kelas label dengan data kategori kelas CEPAT berjumlah 142 dan data kategori kelas LAMBAT berjumlah 128. Probabilitas tiap kelas disajikan pada tabel 2 di bawah ini:

\begin{tabular}{lcc}
\multicolumn{2}{c}{ Tabel 2. Probabilitas Kelas Label } \\
\hline \multicolumn{1}{c}{ Kelas } & Jumlah & $\begin{array}{c}\text { Probabilitas } \\
\text { Kelas P(H) }\end{array}$ \\
\hline CEPAT & 142 & 0,526 \\
LAMBAT & 128 & 0,474 \\
\hline
\end{tabular}

2. Menghitung Probabilitas Setiap Kejadian Perkelas

Untuk mencari nilai probabilitas setiap kejadian perkelas yaitu dengan menghitung jumlah atribut pada kelas CEPAT dan kelas LAMBAT, kemudian dibagi dengan jumlah kelas yang ada. Nilai probabilitas setiap kejadian perkelas sebagai berikut:

a. Probabilitas atribut Jenis Kelamin dapat dilihat pada tabel 3:

Tabel 3. Probabilitas Jenis Kelamin

\begin{tabular}{ccc}
\hline \multirow{2}{*}{ Jenis Kelamin } & \multicolumn{2}{c}{ Probabilitas $(\mathbf{P}(\mathbf{X} \mid \mathbf{H}))$} \\
\cline { 2 - 3 } & CEPAT & LAMBAT \\
\hline Laki-Laki & 0,845 & 0,781 \\
Perempuan & 0,155 & 0,219 \\
\hline
\end{tabular}

b. Probabilitas atribut Angkatan dapat dilihat pada tabel 4:

\begin{tabular}{ccc}
\multicolumn{2}{c}{ Tabel 4. Probabilitas Angkatan } \\
\hline \multirow{2}{*}{ Angkatan } & \multicolumn{2}{c}{ Probabilitas (P(X|H)) } \\
\cline { 2 - 3 } & CEPAT & LAMBAT \\
\hline 2009 & 0,056 & 0,016
\end{tabular}

\begin{tabular}{lll}
2010 & 0,042 & 0,008 \\
2011 & 0,127 & 0,086 \\
2012 & 0,183 & 0,102 \\
2013 & 0,218 & 0,141 \\
2014 & 0,183 & 0,258 \\
2015 & 0,106 & 0,195 \\
2016 & 0,085 & 0,195 \\
\hline
\end{tabular}

c. Probabilitas atribut Tahun Lulus dapat dilihat pada tabel 5:

Tabel 5. Probabilitas Tahun Lulus

\begin{tabular}{ccc}
\multicolumn{2}{c}{ Tabel 5. Probabilitas Tahun Lulus } \\
\hline \multirow{2}{*}{ Tahun Lulus } & \multicolumn{2}{c}{ Probabilitas $(\mathbf{P}(\mathbf{X} \mid \mathbf{H}))$} \\
\cline { 2 - 3 } & CEPAT & LAMBAT \\
\hline 2013 & 0,042 & 0,016 \\
2014 & 0,035 & 0,008 \\
2015 & 0,070 & 0,047 \\
2016 & 0,021 & 0,039 \\
2017 & 0,113 & 0,094 \\
2018 & 0,225 & 0,273 \\
2019 & 0,296 & 0,297 \\
2020 & 0,197 & 0,227 \\
\hline
\end{tabular}

d. Probabilitas atribut IPK dapat dilihat pada tabel 6:

\begin{tabular}{ccc}
\multicolumn{2}{c}{ Tabel 6. Probabilitas IPK } \\
\hline \multirow{2}{*}{ IPK } & \multicolumn{2}{c}{ Probabilitas $(\mathbf{P}(\mathbf{X} \mid \mathbf{H}))$} \\
\cline { 2 - 3 } & CEPAT & LAMBAT \\
\hline Sampel Uji $=3,00$ & 0,472 & 0,333 \\
\hline
\end{tabular}

e. Probabilitas atribut Lama Studi dapat dilihat pada tabel 7:

Tabel 7. Probabilitas Lama Studi

\begin{tabular}{ccc}
\hline \multirow{2}{*}{ Lama Studi } & \multicolumn{2}{c}{ Probabilitas $(\mathbf{P}(\mathbf{X} \mid \mathbf{H}))$} \\
\cline { 2 - 3 } & CEPAT & LAMBAT \\
\hline 3,5 - 4 Tahun & 0,437 & 0,633 \\
> 4 Tahun & 0,563 & 0,367 \\
\hline
\end{tabular}

f. Probabilitas atribut Riwayat Organisasi/ Kepanitiaan dapat dilihat pada tabel 8 :

\begin{tabular}{ccc}
\multicolumn{3}{c}{$\begin{array}{c}\text { Tabel 8. Probabilitas Riwayat } \\
\text { Organisasi/Kepanitiaan }\end{array}$} \\
\hline $\begin{array}{c}\text { Riwayat } \\
\text { Organisasi/ } \\
\text { Kepanitiaan }\end{array}$ & Probabilitas (P(X|H)) \\
\cline { 2 - 3 } CEPAT & LAMBAT \\
\hline 1 & 0,373 & 0,328 \\
2 & 0,155 & 0,164 \\
3 & 0,246 & 0,203 \\
4 & 0,134 & 0,172 \\
5 & 0,092 & 0,133 \\
\hline
\end{tabular}

g. Probabilitas atribut Pengalaman Magang/Kerja dapat dilihat pada tabel 9:

\begin{tabular}{ccc}
\multicolumn{2}{c}{ Tabel 9. Probabilitas Pengalaman } \\
Magang/Kerja \\
\hline $\begin{array}{c}\text { Pengalaman } \\
\text { Magang/ }\end{array}$ & \multicolumn{2}{c}{ Probabilitas $(\mathbf{P}(\mathbf{X} \mid \mathbf{H}))$} \\
\cline { 2 - 3 } Kerja & CEPAT & LAMBAT \\
\hline Ada & 0,761 & 0,625 \\
Tidak & 0,239 & 0,375 \\
\hline
\end{tabular}

h. Probabilitas atribut Memiliki Sertifikasi Keahlian dapat dilihat pada tabel 10 : 


\begin{tabular}{ccc}
\multicolumn{3}{c}{ Tabel 10. Probabilitas Memiliki } \\
Sertifikasi Keahlian \\
\hline Memiliki & \multicolumn{2}{c}{ Probabilitas (P(X|H)) } \\
\cline { 2 - 3 } $\begin{array}{c}\text { Sertifikasi } \\
\text { Keahlian }\end{array}$ & CEPAT & LAMBAT \\
\hline Ada & 0,535 & 0,578 \\
Tidak & 0,465 & 0,422 \\
\hline
\end{tabular}

i. Probabilitas atribut Bidang Pekerjaan dapat dilihat pada tabel 11:

Tabel 11. Probabilitas Bidang Pekerjaan

\begin{tabular}{ccc}
\hline Bidang & \multicolumn{2}{c}{ Probabilitas $(\mathbf{P}(\mathbf{X} \mid \mathbf{H}))$} \\
\cline { 2 - 3 } Pekerjaan & CEPAT & LAMBAT \\
\hline $\begin{array}{c}\text { Pegawai } \\
\text { Swasta }\end{array}$ & 0,915 & 0,969 \\
$\begin{array}{c}\text { Pegawai } \\
\text { Negeri } \\
\text { Sipil }\end{array}$ & 0,085 & 0,031 \\
\hline
\end{tabular}

j. Probabilitas atribut Jenis Perusahaan dapat dilihat pada tabel 12 :

\begin{tabular}{ccc}
\multicolumn{2}{c}{ Tabel 12 Probabilitas Jenis Perusahaan } \\
\hline Jenis & \multicolumn{2}{c}{ Probabilitas $(\mathbf{P}(\mathbf{X} \mid \mathbf{H}))$} \\
\cline { 2 - 3 } Perusahaan & CEPAT & LAMBAT \\
\hline Lokal/Daerah & 0,472 & 0,469 \\
Nasional & 0,324 & 0,367 \\
Multinasional & 0,204 & 0,164 \\
\hline
\end{tabular}

k. Probabilitas atribut Kota Tempat Bekerja dapat dilihat pada tabel 13:

Tabel 13. Probabilitas Kota Tempat Bekerja

\begin{tabular}{ccc}
\hline Kota & \multicolumn{2}{c}{ Probabilitas $(\mathbf{P}(\mathbf{X} \mid \mathbf{H}))$} \\
\cline { 2 - 3 } $\begin{array}{c}\text { Tempat } \\
\text { Bekerja }\end{array}$ & CEPAT & LAMBAT \\
\hline Karawang & 0,718 & 0,500 \\
Luar & 0,282 & 0,500 \\
Karawang & 0,282 \\
\hline
\end{tabular}

1. Probabilitas atribut Kesesuaian Bidang Pekerjaan dengan TI dapat dilihat pada tabel 14:

Tabel 14. Probabilitas Kesesuaian Bidang Pekerjaan dengan TI

\begin{tabular}{|c|c|c|}
\hline \multirow{2}{*}{$\begin{array}{c}\text { Kesesuaian } \\
\text { Bidang } \\
\text { Pekerjaan } \\
\text { dengan TI }\end{array}$} & \multicolumn{2}{|c|}{ Probabilitas $(\mathbf{P}(\mathbf{X} \mid \mathbf{H}))$} \\
\hline & CEPAT & LAMBAT \\
\hline 1 & 0,331 & 0,195 \\
\hline 2 & 0,246 & 0,383 \\
\hline 3 & 0,423 & 0,422 \\
\hline
\end{tabular}

3. Kalikan Hasil Variabel

Dari perhitungan probabilitas yang telah dilakukan sebelumnya dapat digunakan untuk melakukan proses prediksi pada data uji seperti pada tabel 15 dengan cara mengalikan setiap atribut perkelas.

\begin{tabular}{clc}
\multicolumn{3}{c}{ Tabel 15. Sampel Data Uji } \\
\hline No & \multicolumn{1}{c}{ Atribut } & Keterangan \\
\hline 1 & Jenis Kelamin & Laki-Laki \\
2 & Angkatan & 2012 \\
3 & Tahun Lulus & 2018 \\
4 & IPK & 3,00
\end{tabular}



1. Kelas CEPAT

$=\mathrm{P}($ CEPAT $) \times \mathrm{P}($ Jenis Kelamin $=$ Laki-Laki CEPAT $) \times \mathrm{P}($ Angkatan $=2012 \mid$ CEPAT $) \times \mathrm{P}$ $($ Tahun Lulus $=2018 \mid$ CEPAT $) \times P($ IPK $=3,00$ $\mid$ CEPAT $) \times P($ Lama Studi $=>4$ Tahun $\mid$ CEPAT) $\times$ P (Riwayat Organisasi/Kepanitiaan $=3 \mid$ CEPAT $) \times \mathrm{P}($ Pengalaman Magang $/$ Kerja $=$ Ada $\mid$ CEPAT $) \times P($ Memiliki Sertifikasi Keahlian $=$ Ada $\mid$ CEPAT $) \times P($ Bidang Pekerjaan $=$ Pegawai Swasta $\mid$ CEPAT $) \times P$ $($ Jenis Perusahaan $=$ Nasional $\mid$ CEPAT $) \times P$ $($ Kota Tempat Bekerja $=$ Karawang $\mid$ CEPAT $) \times$ $\mathrm{P}$ (Kesesuaian Bidang Pekerjaan dengan TI = 3 | CEPAT)

$=0,526 \times 0,845 \times 0,183 \times 0,225 \times 0,472 \times$ $0,563 \times 0,246 \times 0,761 \times 0,535 \times 0,915 \times 0,324$ $\times 0,718 \times 0,423$

$=4,38562 \mathrm{E}-05$

$=0,0000438562$

2. Kelas LAMBAT

$=\mathrm{P}($ LAMBAT $) \times \mathrm{P}($ Jenis Kelamin $=$ Laki Laki $\mid$ LAMBAT $) \times P($ Angkatan $=2012 \mid$ LAMBAT $) \times \mathrm{P}$ (Tahun Lulus $=2018$ LAMBAT $) \times \mathrm{P}($ IPK $=3,00 \mid$ LAMBAT $) \times \mathrm{P}$ $($ Lama Studi $=>4$ Tahun $\mid$ LAMBAT $) \times \mathrm{P}$ (Riwayat Organisasi/Kepanitiaan $=3$ | LAMBAT $) \times \mathrm{P}($ Pengalaman Magang $/$ Kerja $=$ Ada $\mid$ LAMBAT) $\times$ P (Memiliki Sertifikasi Keahlian $=$ Ada $\mid$ LAMBAT $) \times P($ Bidang Pekerjaan = Pegawai Swasta $\mid$ LAMBAT $) \times \mathrm{P}$ $($ Jenis Perusahaan $=$ Nasional $\mid$ LAMBAT $) \times P$ $($ Kota Tempat Bekerja $=$ Karawang $\mid$ LAMBAT $)$ $\times \mathrm{P}($ Kesesuaian Bidang Pekerjaan dengan $\mathrm{TI}=$ 3 | LAMBAT) $=0,474 \times 0,781 \times 0,102 \times 0,273 \times 0,333 \times 0,367$ $\times 0,203 \times 0,625 \times 0,578 \times 0,969 \times 0,367 \times 0,500$ $\times 0,422$

$=6,93232 \mathrm{E}-06$

$=0,00000693232$

\section{Membandingkan Hasil Variabel}

Nilai probababilitas terbesar dari hasil perhitungan pada kelas label akan dijadikan sebagai masukan data uji tersebut [20]. Dari perhitungan manual sebelumnya dengan mengkalikan hasil variabel dengan menggunakan sampel data uji, didapat hasil pada kelas CEPAT dengan nilai probabilitas 4,38562E-05, dan hasil pada kelas LAMBAT dengan nilai probabilitas 6,93232E-06. Apabila dibandingkan dari perhitungan Nä̈ve Bayes 
tersebut, nilai probabilitas tertinggi yaitu pada kelas prediksi (P | CEPAT). Maka diperoleh kesimpulan bahwa data uji tersebut masuk ke dalam kelas prediksi lama waktu mendapatkan pekerjaan CEPAT.

\subsection{Pembahasan}

Berdasarkan tabel 16 di bawah, maka skenario ke-sembilan dengan 10-Folds Cross Validation merupakan skenario terbaik dengan nilai Accuracy sebesar 67,78\% dan Kappa 0,356.

Tabel 16 Perbandingan Evaluasi Nä̈ve Bayes

\begin{tabular}{cccc}
\hline Skenario & $\boldsymbol{k}$-folds & Accuracy & Kappa \\
\hline 1 & 2 & $64,81 \%$ & 0,293 \\
2 & 3 & $64,81 \%$ & 0,294 \\
3 & 4 & $64,07 \%$ & 0,282 \\
4 & 5 & $64,81 \%$ & 0,296 \\
5 & 6 & $67,41 \%$ & 0,346 \\
6 & 7 & $65,19 \%$ & 0,302 \\
7 & 8 & $65,93 \%$ & 0,315 \\
8 & 9 & $67,41 \%$ & 0,346 \\
9 & 10 & $67,78 \%$ & 0,356 \\
\hline
\end{tabular}

Berdasarkan tabel 17 di bawah, maka skenario ke-sembilan dengan 10-Folds Cross Validation merupakan skenario terbaik dengan memiliki nilai evaluasi Accuracy sebesar 68,52\% dan Kappa 0,370.

Tabel 17. Perbandingan Evaluasi Nä̈ve Bayes

\begin{tabular}{cccc}
\multicolumn{5}{c}{+ Backward Elimination } \\
\hline Skenario & $\boldsymbol{k}$-folds & Accuracy & Kappa \\
\hline 1 & 2 & $68,52 \%$ & 0,370 \\
2 & 3 & $67,78 \%$ & 0,354 \\
3 & 4 & $67,04 \%$ & 0,341 \\
4 & 5 & $67,78 \%$ & 0,354 \\
5 & 6 & $67,41 \%$ & 0,349 \\
6 & 7 & $67,41 \%$ & 0,348 \\
7 & 8 & $68,52 \%$ & 0,370 \\
8 & 9 & $67,78 \%$ & 0,354 \\
9 & 10 & $68,52 \%$ & 0,370 \\
\hline
\end{tabular}

Evaluasi dengan 10-Folds Cross Validation menggunakan nilai Accuracy menghasilkan model Nä̈ve Bayes dengan fitur seleksi Backward Elimination mampu meningkatkan kinerja pemodelan berdasarkan nilai Accuracy. Dapat dilihat perbandingannya pada gambar 3 berikut ini.

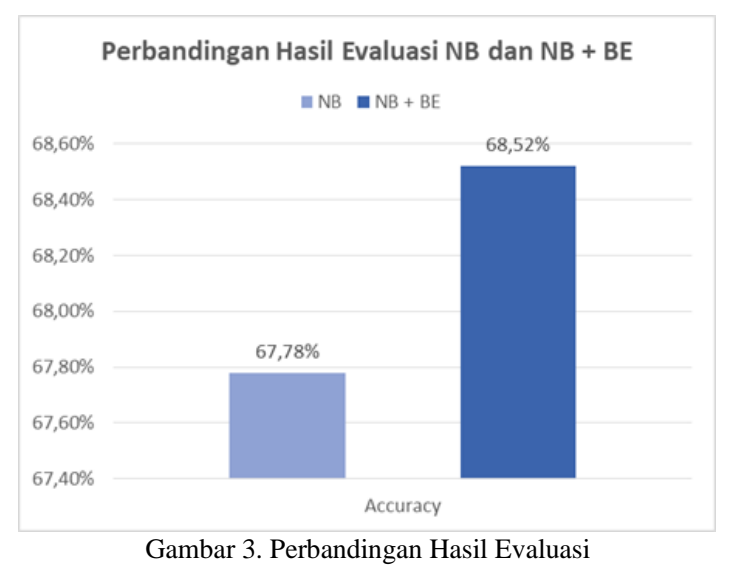

Evaluasi dengan 10-Folds Cross Validation menggunakan nilai Kappa menghasilkan model
Nä̈ve Bayes dengan fitur seleksi Backward Elimination mampu meningkatkan kinerja pemodelan berdasarkan nilai Kappa yang meningkat dari 0,356 menjadi 0,370 seperti pada gambar 4 berikut.

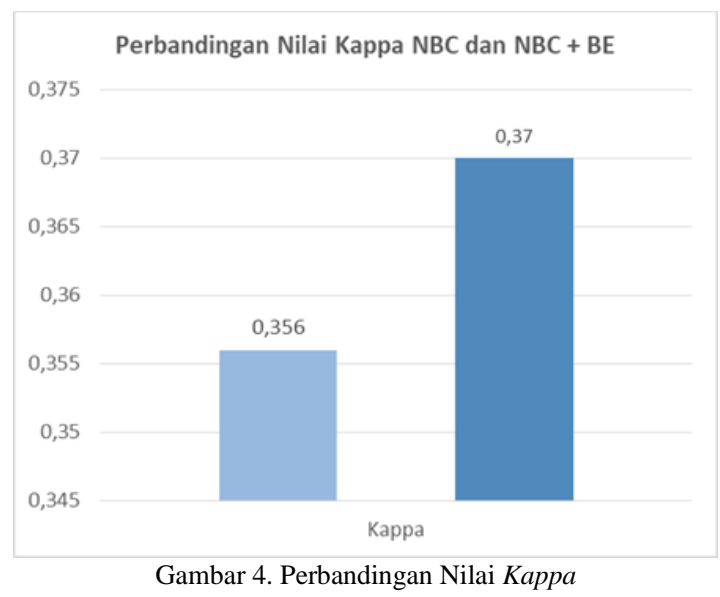

Tabel 18 di bawah menunjukkan bahwa pada fitur seleksi Backward Elimination, atribut yang dianggap tidak berpengaruh pada pengujian 10-Folds Cross Validation yaitu atribut IPK dan atribut Riwayat Organisasi/Kepanitiaan.

\begin{tabular}{lc}
\multicolumn{2}{c}{ Tabel 18. Atribut Berpengaruh Backward Elimination } \\
\hline \multicolumn{1}{c}{ Atribut } & Weight \\
\hline Jenis Kelamin & 1 \\
Angkatan & 1 \\
Tahun Lulus & 1 \\
IPK & 0 \\
Lama Studi & 1 \\
Riwayat Organisasi/Kepanitiaan & 0 \\
Pengalaman Magang/Kerja & 1 \\
Memiliki Sertifikasi Keahlian & 1 \\
Bidang Pekerjaan & 1 \\
Jenis Perusahaan & 1 \\
Kota Tempat Bekerja & 1 \\
Kesesuaian Bidang Pekerjaan & 1 \\
dengan TI & \\
Lama Waktu Mendapatkan & 1 \\
Pekerjaan &
\end{tabular}

\section{KESIMPULAN}

Dari penelitian yang telah dilakukan dapat disimpulkan bahwa:

1. Hasil dari semua pengujian yang telah dilakukan dengan 9 skenario uji menggunakan $K$-Fold Cross Validation diketahui bahwa pada pemodelan Nä̈ve Bayes dihasilkan performa terbaik dengan 10-Folds Cross Validation. Pengujian menghasilkan nilai evaluasi Accuracy sebesar 67,78\% dan Kappa 0,356.

2. Pada pemodelan Nä̈ve Bayes dengan fitur seleksi Backward Elimination menghasilkan nilai evaluasi tertinggi dengan menggunakan 10-Folds Cross Validation. Menghasilkan nilai evaluasi Accuracy sebesar 68,52\% dan Kappa 0,370 . 
3. Algoritma Nä̈ve Bayes dengan Fitur seleksi Backward Elimination terbutki dapat meningkatkan hasil evaluasi pada prediksi waktu tunggu alumni mendapatkan pekerjaan.

\section{DAFTAR PUSTAKA}

[1] C. D. Casuat dan E. D. Festijo. 2020. "Identifying the Most Predictive Attributes Among Employability Signals of Undergraduate Students", 16th IEEE International Colloquium on Signal Processing $\&$ its Applications,

[2] DIKTI. Tracer Study. 2021. "Tentang Tracer Study"., Tersedia [http://tracerstudy.kemdikbud. go.id/index.php/site/about]. diakses 12 Februari 2021.

[3] Asroni, N. M. Ali dan S. Riyadi. 2018. "Perkiraan Masa Tunggu Alumni Mendapatkan Pekerjaan Menggunakan Metode Prediksi Data Mining Dengan Algoritma Naive Bayes Classifier"., Semesta Teknika, Vol. 21(2), pp. 189-197.

[4] M. A. Maricar dan D. Pramana. 2019. "Perbandingan Akurasi Naïve Bayes dan KNearest Neighbor pada Klasifikasi untuk Meramalkan Status Pekerjaan Alumni ITB STIKOM Bali”., Jurnal Sistem dan Informatika (JSI), Vol. 14(1), pp. 16-22.

[5] I. M. B. Adnyana. 2020. "Implementasi Naïve Bayes Untuk Memprediksi Waktu Tunggu Alumni Dalam Memperoleh Pekerjaan"., Seminar Nasional Teknologi Komputer \& Sains (SAINTEKS), pp. 131-134.

[6] R. Resmiati dan T. Arifin. 2021. "Klasifikasi Pasien Kanker Payudara Menggunakan Metode Support Vector Machine dengan Backward Elimination"., SISTEMASI: Jurnal Sistem Informasi, Vol. 10(2), pp. 381-393.

[7] D. M. A. North. 2016. Data Mining for the Masses, Second Edition.

[8] D. T. Larose dan C. D. Larose. 2014. Discovering Knowledge in Data an Introduction to Data Mining 2nd Edition, Hoboken, New Jersey: John Wiley \& Sons, Inc.

[9] A. G. Lazuardy dan H. Setiaji. 2019. "Data Cleansing pada Data Rumah Sakit"., Proceeding SINTAK, Vol.3, pp. 242-248.

[10] H. A. Chusna dan A. T. Rumiati. 2020. "Penerapan Metode K-Means dan Fuzzy CMeans untuk Pengelompokan Sekolah Menengah Pertama (SMP) di Indonesia Berdasarkan Standar Nasional Pendidikan (SNP)",, JURNAL SAINS DAN SENI ITS, Vol. 9(2), pp. 216-223.

[11] I. L. Uruilal, C. J. Supit dan T. Jansen. 2020. "Prediksi Banjir di Sungai Ranowangko Kecamatan Amurang Kabupaten Minahasa
Selatan”., Jurnal Sipil Statik, Vol. 8(2), pp. 167174.

[12] Y. E. Ardiningtyas dan P. H. Prima Rosa. 2021. "Analisis Balancing Data untuk Meningkatkan Akurasi dalam Klasifikasi”., Prosiding Seminar Nasional Aplikasi Sains \& Teknologi (SNAST), pp. 24-28.

[13] A. Indrawati. 2021. "Penerapan Teknik Kombinasi Oversampling dan Undersampling untuk Mengatasi Permasalahan Imbalanced Dataset"., JIKO (Jurnal Informatika dan Komputer), Vol. 4(1), pp. 38-43.

[14] M. Sadikin, R. Rosnelly, Roslina, T. S. Gunawan dan Wanayumini. 2020. "Perbandingan Tingkat Akurasi Klasifikasi Penerimaan Dosen Tetap Menggunakan Metode Naive Bayes Classifier dan C4.5"., Jurnal Media Informatika Budidarma, Vol. 4(4), pp. 1100-1009.

[15] D. Alita, I. Sari, A. R. Isnain dan Styawati. 2021. "Penerapan Naïve Bayes Classifier untuk Pendukung Keputusan Penerima Beasiswa"., JDMSI, Vol. 2(1), pp. 17-23.

[16] M. F. Aziz, S. Defiyanti dan B. N. Sari. 2018. "Perbandingan Algoritma Cart dan K-Nearest Neighbor untuk Prediksi Luas Lahan Panen Tanaman Padi di Kabupaten Karawang"., Jurnal TAM (Technology Acceptance Model), Vol. 9(2), pp. 74-78.

[17] M. R. Fanani. 2020. “Algoritma Naive Bayes Berbasis Forward Selection Untuk Prediksi Bimbingan Konseling Siswa", Jurnal DISPROTEK, Vol. 11(1), pp. 13-22.

[18] S. P. Nabila, N. Ulinnuha dan A. Yusuf. 2021. "Model Prediksi Kelulusan Tepat Waktu dengan Metodefuzzy C-Means dan K-Nearest Neighbors Menggunakan Data Registrasi Mahasiswa”., Jurnal Ilmiah NERO, Vol. 6(1), pp. 39-47.

[19] V. Pynam, R. R. Spanadna and K. Srikanth. 2018. "An Extensive Study of Data Analysis Tools (Rapid Miner, Weka, R Tool, Knime, Orange)"., SSRG International Journal of Computer Science and Engineering, Vol. 5(9) pp. 4-11.

[20] D. Sartika dan D. I. Sensuse. 2017. "Perbandingan Algoritma Klasifikasi Naive Bayes, Nearest Neighbour, dan Decision Tree pada Studi Kasus Pengambilan Keputusan Pemilihan Pola Pakaian”., Jatisi, Vol. 1(2), pp. $151-161$. 